\title{
Cognitive behavioral therapy for anxiety disorders
}

Citation for published version (APA):

Vos, S. P. F. (2019). Cognitive behavioral therapy for anxiety disorders: Does One size fit all. [Doctoral Thesis, Maastricht University]. https://doi.org/10.26481/dis.20191206sv

Document status and date:

Published: 01/01/2019

DOI:

10.26481/dis.20191206sv

Document Version:

Publisher's PDF, also known as Version of record

\section{Please check the document version of this publication:}

- A submitted manuscript is the version of the article upon submission and before peer-review. There can be important differences between the submitted version and the official published version of record.

People interested in the research are advised to contact the author for the final version of the publication, or visit the DOI to the publisher's website.

- The final author version and the galley proof are versions of the publication after peer review.

- The final published version features the final layout of the paper including the volume, issue and page numbers.

Link to publication

\footnotetext{
General rights rights.

- You may freely distribute the URL identifying the publication in the public portal. please follow below link for the End User Agreement:

www.umlib.nl/taverne-license

Take down policy

If you believe that this document breaches copyright please contact us at:

repository@maastrichtuniversity.nl

providing details and we will investigate your claim.
}

Copyright and moral rights for the publications made accessible in the public portal are retained by the authors and/or other copyright owners and it is a condition of accessing publications that users recognise and abide by the legal requirements associated with these

- Users may download and print one copy of any publication from the public portal for the purpose of private study or research.

- You may not further distribute the material or use it for any profit-making activity or commercial gain

If the publication is distributed under the terms of Article $25 \mathrm{fa}$ of the Dutch Copyright Act, indicated by the "Taverne" license above, 
Summary 
Anxiety disorders are one of the most prevalent mental health problems. The course of an anxiety disorder tends to be chronic if it is left untreated. The duration of complaints can be years, even decades. Comorbidity rates in patients with an anxiety disorder are very high. Cognitive behavioral treatment (CBT) techniques are considered the gold-standard in psychological treatment for anxiety disorders. The efficacy and effectiveness of cognitive-behavioral treatments have been studied in numerous randomized controlled or clinical trials (RCT's) and uncontrolled trials. The results of these studies show convincingly that patients with an anxiety disorder can be successfully treated with cognitive and behavioral techniques. Although the short-term efficacy of CBT treatments for anxiety disorders is impressive, CBT is not a panacea. A considerable number of patients is (in the long-term) not relieved from their symptoms by treatment with CBT, due to treatment dropout, nonresponse and symptom relapse. Studies in this area are plagued by conceptual and methodological problems, which limits the conclusions that can be drawn from them. The main purpose of the present thesis is to contribute to the study of anxiety disorder treatment beyond the point of proven effectiveness of CBT: To contribute to further clarification of the issues of mechanisms of change of CBT, predictors of outcome of CBT, dismantling of CBT treatment, the relative effectiveness among cognitive therapie (CT), behavioral therapy (BT) and combined CBT treatments, and the investigation of IPT as a possible additional effective treatment for anxiety disorders besides CBT. This summary gives a short overview of each chapter in the thesis.

In the general introduction in chapter 1 definitions of anxiety disorders, CBT and IPT are provided. The clinical expression and prevalence of anxiety disorders is discussed as well as CBT and the possibility of IPT treatment of anxiety disorders. Limitations of CBT treatment and CBT treatment research are discussed and the concepts of predictors of outcome and mechanisms of change are introduced.

Chapter 2 presents a randomized clinical trial of IPT vs. CBT in the treatment of panic disorder with agoraphobia. The effectiveness of these treatments was investigated in ninety-one adult patients with a primary diagnosis of DSM-III or DSM-IV panic disorder with agoraphobia. Primary outcomes were panic attack frequency and an idiosyncratic behavioral test. Secondary outcomes were panic and agoraphobia severity, panic-related cognitions, interpersonal functioning and general psychopathology. Measures were taken at 0,3 and 4 months (baseline, end of treatment, and follow-up). Intention-to-treat analyses on the primary outcomes indicated the superior effects of CBT for the treatment of a panic disorder with agoraphobia. Per-protocol analyses emphasized the differences between the treatments, and yielded larger effect sizes. Reductions in the secondary outcomes were equal for both treatments, except for agoraphobic complaints and behavior, 
and the credibility ratings of negative interpretations of bodily sensations, all of which decreased more in CBT. The results indicate that CBT is the treatment of preference for panic disorder with agoraphobia over IPT.

In chapter 3 a study on the mediation of therapy effects of CBT vs. IPT treatment for panic disorder with agoraphobia is discussed. Symptom change in CBT is thought to result from change in the conditioned anxiety response and maladaptive cognitions, change in IPT through change in interpersonal functioning. However, in the clinical trial described in chapter 2, CBT was more effective than IPT. The aim of the study in the present chapter was to explore what mediated this condition effect between CBT and IPT: fear of fear, cognitive beliefs or interpersonal functioning. Outcome measures were change in panic attack frequency and avoidance behaviour. Classical mediation analyses, the Sobel test, per protocol regression analyses, and investigated temporal relationships between change during and after treatment were conducted. Change in CBT was larger compared to change in IPT for all potential mediators (including interpersonal functioning) and outcome measures. Change in fear of fear was the main mediator between condition effect and change in panic attack frequency, and change in cognitive beliefs was the main mediator between condition effect and change in avoidance behaviour, both in CBT and IPT. Additionally, change in panic attack frequency and avoidance behaviour seemed unrelated to each other. No temporal relationships could be identified. Mediating effects seem to be similar in CBT and IPT, and are in line with the theoretical underpinnings of CBT.

Chapter 4 contains the description of the results of a randomized clinical trial of IPT vs. CBT in the treatment of panic disorder without agoraphobia. Seventy adult patients with a primary diagnosis of DSM-III or DSM-IV panic disorder without agoraphobia were randomized. Primary outcomes were panic attack frequency and an idiosyncratic behavioral test. Secondary outcomes were panic severity, panic-related cognitions, interpersonal functioning and general psychopathology. Measures were taken at 0,3 and 4 months (baseline, end of treatment, and follow-up). Intentionto-treat analyses on the primary outcome measures indicated a superior effect of CBT on improvement of panic-related behavior, panic attack frequency reduced equally in both treatments. Also reductions in the secondary outcomes were equal for both treatments, except for the credibility ratings of negative interpretations of bodily sensations which decreased more in CBT. Although the results of IPT seem somewhat more favorable than in the panic disorder with agoraphobia trial (Chapter 2), the results nevertheless suggest that CBT is superior as a treatment for panic disorder without agoraphobia. 
In chapter 5 an experimental study on the relative efficacy of CT targeted on inflated beliefs of responsibility (CT-R) versus CT targeted on overestimations of danger (CT-D) in the treatment of DSM-III/DSM-IV obsessive compulsive disorder (OCD) with overt compulsions is discussed. Seventy-eight patients were randomized over CT-R and CT-D. Outcomes were change in OCD symptoms and behaviour, cognitions and general psychopathology. Measures were taken at 0,3 and 4 months (baseline, end of treatment, and follow-up). Therapy effect sizes were large in both conditions for improvement on OCD symptoms as well as OCD related behaviour. Dropout rates were quite low in both conditions suggesting the treatments to be well tolerable. Both treatment targets had efficacious elements in CT for OCD and equivalent value for treatment outcome. Results show that the target on inflated beliefs of personal responsibility is a helpful element in the treatment of OCD, and they add to the evidence supporting the role of personal feelings of responsibility in the maintenance of OCD.

Chapter 6 describes the results of a mega-analysis investigating treatment effects and predictors of treatment outcome and drop-out across CBT treatments and anxiety disorders. The routinely assessed data of 15 randomized clinical trials with CBT, CT, BT and non-CBT treatments were analyzed with multilevel analyses. The methodology of the 15 trials was comparable. The primary outcome measures were change in general psychopathology and drop-out. Measures were taken at 0, 3, 4 and 9 months. Investigated predictors were all pretreatment patient characteristics. Intention-to-treat analyses of change in general psychopathology indicated superior effects of combined CBT for the treatment of anxiety disorders. Drop-out rate differed among the anxiety disorders. Educational level, comorbid Axis I and Axis-II disorder, use of psychoactive medication and the interaction of duration of complaints and anxiety disorder predicted general psychopathology at $0,3,4$ and 9 months, but not a difference in improvement. Work level was a prescriptive predictor of drop-out. The results of the study emphasize the importance of treating an axis-I anxiety disorder, preferably with CBT and regardless of the additional characteristics of patients and their symptoms.

In chapter 7 the results from the present thesis were integrated and discussed. Methodological considerations, future directions and clinical implications are deliberated. 
Appendix

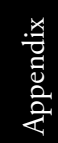

175 
Samenvatting

(Dutch summary) 
Angststoornissen behoren tot de meest voorkomende geestelijke gezondheidsproblemen. Het verloop van een angststoornis is meestal chronisch als deze niet behandeld wordt. De klachten kunnen jaren, soms zelfs tientallen jaren duren, en co-morbiditeit is hoog bij patiënten met een angststoornis. Cognitieve gedragstherapie (CGT) technieken worden beschouwd als de gouden standaard in psychologische behandeling voor angststoornissen. De effectiviteit van cognitieve gedragsbehandelingen is onderzocht in vele gerandomiseerde en gecontroleerde of klinische trials en ongecontroleerde trials. De resultaten van deze studies laten overtuigend zien dat patiënten met een angststoornis succesvol behandeld kunnen worden met cognitieve en gedragstechnieken. Hoewel de effectiviteit van CGT behandelingen voor angststoornissen op korte termijn indrukwekkend is, is CGT geen panacee. Een aanzienlijk deel van de patiënten is (op de lange termijn) niet verlost van de angstsymptomen door CGT, als gevolg van vroegtijdige uitval uit behandeling, niet reageren op de behandeling en terugval. Studies op dit gebied worden geplaagd door conceptuele en methodologische problemen die de conclusies die eruit kunnen worden getrokken beperken. Het belangrijkste doel van de huidige thesis is een bijdrage te leveren aan het onderzoek naar behandeling van angststoornissen voorbij het punt van bewezen effectiviteit van CGT: Om bij te dragen aan verdere verheldering van de issues van veranderingsmechanismen, voorspellers van therapie uitkomst van CGT, de ontmanteling van CGT, de relatieve effectiviteit van gedragstherapie (GT) cognitieve therapie (CT) en gecombineerde CGT behandeling, en de studie van IPT als mogelijke aanvullende effectieve behandeling voor angststoornissen naast CGT. Deze samenvatting geeft een kort overzicht van elk hoofdstuk in de thesis.

In de algemene introductie in hoofdstuk 1 worden angststoornissen, CGT en IPT gedefinieerd. Angststoornissen worden vanuit klinisch perspectief besproken, prevalentiecijfers worden gegeven en CGT wordt als behandeling en IPT als mogelijke behandeling voor angststoornissen besproken. De beperkingen van CGT en het onderzoek naar CGT komen aan bod en de concepten veranderingsmechanismen en voorspellers van therapie uitkomst worden geïntroduceerd.

In hoofdstuk 2 worden de resultaten van een gerandomiseerde klinische trial van IPT vs. CGT voor paniekstoornis met agorafobie besproken. De effectiviteit van deze behandelingen werd onderzocht bij eenennegentig volwassen patiënten met een DSM-III of DSM-IV primaire diagnose van paniekstoornis met agorafobie. De primaire uitkomstmaten waren frequentie van paniekaanvallen en een idiosyncratische gedragstest. Secundaire uitkomstmaten waren ernst van paniek en agorafobie, paniek gerelateerde cognities, interpersoonlijk functioneren en algemene psychopathologie. Metingen vonden plaats op 0, 3 en 4 maanden (voor 
behandeling, na behandeling en 1 maand follow-up). Analyses van de primaire uitkomstmaten waarbij vroegtijdige uitvallers uit therapie ook meegenomen werden lieten zien dat CGT in vergelijking met IPT beter wekte als behandeling voor paniekstoornis met agorafobie. Per-protocol analyses benadrukten de verschillen tussen de behandelingen en lieten grotere effectgroottes zien. Verbeteringen op de secundaire uitkomstmaten waren gelijk voor beide behandelingen, behalve voor agora-fobische klachten en gedrag en de geloofwaardigheidsratings van negatieve interpretatie van lichaamssensaties, die allemaal meer verbeterden in CGT. De resultaten laten zien dat CGT de voorkeur heeft boven IPT als behandeling voor paniekstoornis met agorafobie.

In hoofdstuk 3 wordt een studie naar mediatie effecten in CGT versus IPT voor paniekstoornis met agorafobie besproken. Verandering in symptomen in CGT worden verondersteld het resultaat te zijn van verandering in de geconditioneerde angstreactie en dysfunctionele cognities. En verandering in IPT van verandering in interpersoonlijk functioneren. Maar in de klinische studie beschreven in hoofdstuk 2, was CGT effectiever dan IPT. Het doel van de studie in dit hoofdstuk is te onderzoeken wat het conditie effect tussen CGT en IPT medieerde: angst voor de angst, cognitieve overtuigingen of interpersoonlijk functioneren. Uitkomstmaten waren verandering in frequentie van paniekaanvallen en vermijdingsgedrag. Klassieke mediatie analyse, de Sobel-test, per protocol regressie analyses en onderzoek naar temporele relaties tussen veranderingen gedurende en na de behandeling werden uitgevoerd. In CGT was in vergelijking met IPT de verbetering op alle potentiële mediatoren (inclusief interpersoonlijk functioneren) en uitkomstmaten groter. Verandering in angst voor de angst was de belangrijkste mediator tussen het effect van behandelconditie en verandering in frequentie van paniekaanvallen, en verandering in cognitieve overtuigingen was de belangrijkste mediator tussen het effect van behandelconditie en de verandering in vermijdingsgedrag, zowel voor CGT als IPT. Bijkomend schenen verandering in frequentie van paniekaanvallen en verandering in vermijdingsgedrag niet gerelateerd aan elkaar. Er konden geen temporele relaties tussen verandering gedurende en na de therapie geïdentificeerd worden. Mediërende effecten lijken dus hetzelfde te zijn in CGT en IPT, en in overeenstemming met de theoretische grondslagen van CGT.

Hoofdstuk 4 bevat de beschrijving van de resultaten van een gerandomiseerde klinische trial van IPT vs. CGT voor de behandeling van paniekstoornis zonder agorafobie. Zeventig volwassen patiënten met een primaire DSM-III of DSM-IV diagnose van paniekstoornis zonder agorafobie kregen willekeurig IPT of CGT. Primaire uitkomstmaten waren frequentie van paniekaanvallen en een idiosyncratische gedragstest. Secundaire uitkomstmaten waren ernst van paniek, paniek gerelateerde 
cognities, interpersoonlijk functioneren en algemene psychopathologie. Metingen vonden plaats op 0, 3 en 4 maanden (voor behandeling, na behandeling en followup). Analyses van de primaire uitkomstmaten waarbij vroegtijdige uitvallers uit therapie ook meegenomen werden lieten zien dat CGT beter was in vergelijking met IPT in het verbeteren van paniek gerelateerd gedrag, verbetering van frequentie van paniekaanvallen was gelijk in beide behandelingen. Ook verbeteringen op de secundaire uitkomstmaten waren gelijk voor beide behandelingen, behalve voor de geloofwaardigheidsratings van negatieve interpretatie van lichaamssensaties die meer verbeterden in CGT. Hoewel de resultaten van IPT enigszins gunstiger lijken dan in de studie bij paniekstoornis met agorafobie (Hoofdstuk 2), suggereren de resultaten dat CGT ook voor paniekstoornis zonder agorafobie de voorkeursbehandeling is.

In hoofdstuk 5 wordt een experimentele studie naar de relatieve doeltreffendheid van CT gericht op overschatting van verantwoordelijkheid (CT-V) versus CT gericht op overschatting van gevaar (CT-G) in de behandeling van DSM-III/DSM-IV obsessief compulsieve stoornis (OCS) met openlijke compulsies besproken. Achtenzeventig patiënten werden willekeurig ingedeeld bij CT-V of CT-G. Uitkomstmaten waren verandering in OCS symptomen en gedrag, cognities en algemene psychopathologie. Metingen vonden plaat op 0, 3 en 4 maanden (voor behandeling, na behandeling en follow-up). Therapie effectgroottes voor verbetering van OCS symptomen en OCS gerelateerd gedrag waren in beide condities groot. Vroegtijdige uitval was redelijk laag in beide condities wat suggereert dat de behandelingen goed te verdragen waren voor patiënten. Beide therapiedoelen waren doeltreffende elementen in CT voor OCS en van gelijke waarde voor therapie uitkomst. De resultaten laten zien dat een focus op overschatting van verantwoordelijkheid een doelmatig element is in de behandeling van OCS, en ze zijn een toevoeging aan het bewijs voor de rol van gevoelens van verantwoordelijkheid in het in stand houden van OCS.

Hoofdstuk 6 beschrijft de resultaten van een zogenaamde mega-analyse waarin therapie effecten en voorspellers van therapie uitkomst en uitval onderzocht werden voor de verschillende CGT behandelingen en angststoornissen. De ROM (routinely assessed outcome measures) gegevens van 15 gerandomiseerde klinische trials met CGT, CT of GT behandeling werden geanalyseerd met multilevel analyse. De 15 trials hadden een vergelijkbare opzet. De primaire uitkomstmaten waren verandering in algemene psychopathologie en vroegtijdige uitval uit therapie. Metingen vonden plaats op 0, 3, 4 en 9 maanden (voor behandeling, na behandeling, 1 maand follow-up en 6 maanden follow-up). De onderzochte voorspellers waren allemaal kenmerken van de patiënt voor start van de behandeling. Analyses van verandering in algemene psychopathologie waarbij vroegtijdige uitvallers uit therapie ook meegenomen werden lieten zien dat gecombineerde CGT de grootste verbetering 
liet zien in de behandeling van angststoornissen. Mate van vroegtijdige uitval uit therapie verschilde tussen de angststoornissen. Opleidingsniveau, co-morbiditeit op As I en As II, het gebruik van psychoactieve medicatie en de interactie van duur van de klachten en type angststoornis voorspelde algemene psychopathologie op 0, 3, 4 en 9 maanden, maar niet een verschil in verbetering. Werkniveau was een prescriptieve voorspeller van vroegtijdige uitval uit therapie. De resultaten van de studie benadrukken het belang van het behandelen van een As I angststoornis, bij voorkeur met CGT, ongeacht de verdere kenmerken van een patiënt en zijn of haar symptomen.

In hoofdstuk 7 zijn de resultaten van de huidige thesis geïntegreerd en bediscussieerd. Methodologische beschouwingen, toekomstig onderzoek en klinische implicaties worden besproken. 